\title{
LITERATURA OU ANTROPOLOGIA CRIMINAL? O CANGAÇO EM PEDRA BONITA E CANGACEIROS
}

\author{
João Paulo Mansur ${ }^{1}$ \\ ${ }^{1}$ Universidade Federal de Minas Gerais, Studium Iuris, \\ Belo Horizonte, MG, Brasil
}

\section{Introdução: realidade e ficção}

O romancista paraibano José Lins do Rego (1901-1957) ganhou notoriedade ao publicar, entre 1932 e 1943, o conjunto de romances por ele próprio denominado como "Ciclo da cana-de-açúcar". São seis obras, Menino de Engenho, Doidinho, Banguê, Moleque Ricardo, Usina e Fogo Morto, ambientadas na Zona da Mata e no Agreste do Nordeste brasileiro do início do XX. ${ }^{1}$ "José Lins, motor que funciona queimando bagaço de cana", foi alegoria criada por Manuel Bandeira (Rego 2004:79) para falar do pano de fundo desse conjunto de livros: o modo de vida no mundo dos engenhos açucareiros e a sua posterior decadência em virtude da industrialização que se operava no campo (cf. Cândido 1991). Rego traduzia na literatura o declínio histórico dos engenhos. A usina substituía a manufatura do velho banguê, transformando a realidade social à sua volta (cf. Perruci 1978).

Escrever essas narrativas em vista da ruína histórica dos engenhos não foi por acaso. Aproximar realidade e ficção sempre foi um objetivo da estética do paraibano: "Nada me arreda de ligar a arte à realidade, e de arrancar das entranhas da terra a seiva de meus romances ou de minhas ideias" (Rego 1945:5). ${ }^{2}$ Para realizar esse estilo no "Ciclo da cana-de-açúcar", o escritor tinha fartas memórias de sua infância como menino de engenho, época que vivera com seu avô, senhor de engenho (cf. Trigo 2002:32; Hollanda 2012:141; Castello 1961:71). Dizia José Lins do Rego em entrevista a Clóvis de Gusmão. 
A terra é quem manda nos meus romances [...]. O Engenho Corredor foi a minha grande fonte literária. Lembrando-me dele fui escritor, contando a sua história escrevi os meus romances, fiz viver criaturas. Foi a terra que me deu força para trabalhar em 10 livros e realizar 10 romances o que nunca imaginei ser possível. [...]. Vim da terra, sou da terra e quero continuar da terra. O velho engenho Corredor continua a me alimentar, a me dar o que minha imaginação carece. O massapê paraibano tem muito que dar (Gusmão 1991:53).

Além da relevância da memória, a influência do historiador Gilberto Freyre sobre José Lins, seu amigo íntimo, foi decisiva na composição dessas obras do açúcar, propiciando ao romancista criar literatura com base na visão de mundo presente na interpretação histórica realizada por Freyre (cf. Coutinho 1980:13; Almeida 1999:222; Bueno 2015:135). O historiador pernambucano, porém, não pesquisou o "outro Nordeste", o sertanejo, o da civilização do couro, restringindo-se à sociedade açucareira da Zona da Mata e do Agreste, o que obrigaria José Lins do Rego a se reinventar caso quisesse, em seus romances regionalistas sobre o Sertão, manter o estilo de aproximação com a realidade social.

Ao lançar "voo solo" com o "Ciclo do cangaço, misticismo e seca", outro ciclo de obras ${ }^{3}$ composto por Pedra Bonita e Cangaceiros, de 1938 e 1953, José Lins não sofreu com falta de material que deixasse essas narrativas carentes de substrato da sociedade do Nordeste sertanejo. Na ausência da análise social de Freyre, o próprio Lins foi à pesquisa. E o resultado, difuso nessas duas obras literárias, é muito interessante. Não apenas ficção, o "Ciclo do cangaço, misticismo e seca" carrega consigo análises antropológico-sociais acerca das condições de vida no Sertão e sobre dois fenômenos sociais característicos da civilização do couro: o fanatismo religioso e o cangaceirismo. ${ }^{5}$

Um artigo de jornal publicado por Graciliano Ramos em 11 de setembro de 1938, ano de lançamento de Pedra Bonita, mostra José Lins de Rego realizando "pesquisa de campo" ao visitar o cangaceiro Antônio Silvino na prisão. Extrovertido, o romancista paraibano não teve dificuldades em entabular conversas com o "rifle de ouro", seu antigo conhecido da época em que este visitou, em paz, a casa-grande do engenho de seu avô.

Um dos meus companheiros é o escritor José Lins do Rego, que em menino conheceu o sertanejo temível no engenho do coronel José Paulino, hoje famoso por ter figurado em vários romances notáveis. José Lins, em poucas palavras, reata o conhecimento antigo, e Antônio Silvino logo se torna íntimo dele, conta histórias do cangaço, brigas, visitas que fez a outros personagens de romances. Ultimamente, ao sair da prisão, parece que andou nas terras do velho Trombone [tio de José Lins] e, com sisudez e prudência, espalhou conselhos úteis que resolveram certas dificuldades (Ramos 2014:67-68). 
Há também quem compare, com certa medida de razão, algumas histórias encontradas em Cangaceiros com relatos sobre a vida de Lampião (Diégues Júnior 1991:458; Farias 2006:201). De fato, Lins criava personagens homônimos a alguns sujeitos históricos, a exemplo do Padre Cícero e do cangaceiro Antônio Silvino. Para o "governador do Sertão", embora não houvesse correspondência nominal, Aparício o representaria na ficção. No episódio histórico da formação do "exército patriótico" para o combate à guerrilha de Luís Carlos Prestes, Lampião, em negociação realizada pelo deputado Floro Bartolomeu e pelo Padre Cícero, recebeu armas do Estado para combater a coluna (cf. Pericás 2010:158). José Lins do Rego se apropriou deste fato: Aparício, na ficção, se envolveu na mesma trama (Rego 2011b:258). Também, tal como o "bandido zarolho", Aparício perdeu a visão de um dos olhos (Rego 2011b:325). O caboclo Germano foi batizado por Aparício com a alcunha de Corisco, famoso oficial de Lampião (Rego 2011b:168). Tanto Virgulino quanto Aparício são oriundos de Vila Bela (cf. Oliveira 1970:20). Não se trata, obviamente, de uma biografia. Há mais diferenças que semelhanças. Mas a apropriação da história pelo romance indica a preocupação de José Lins do Rego em manter "a terra", a realidade social, como inspiração também do ciclo sertanejo e evidencia a pesquisa preliminar à confecção dos romances.

Objetiva-se com este artigo expor o pano de fundo dos livros sertanejos de José Lins do Rego no que se refere ao fenômeno do cangaço. Deixaremos para abordar em outro momento o fanatismo religioso. Das narrativas se extrairá a interpretação sociocriminológica de José Lins do Rego sobre o cangaço. Ao tratar o tema, o romancista precisou se situar em relação a algumas interpretações sobre o cangaceirismo que eram habituais em sua época. Elas vão desde teorias sociais que compreendiam o cangaço como banditismo social, para as quais o cangaceiro seria uma espécie de Robin Hood do Sertão, que enfrentava o Estado e os coronéis opressores do povo, até a antropologia criminal da Escola Positiva brasileira, para a qual o cangaceiro seria produto de uma raça humana atavicamente degenerada. Rego, porém, soube se desviar destas duas armadilhas: cangaceiros e coronéis são grupos sociais constitutivos das mesmas relações sociais estabelecidas no Sertão nordestino coronelista.

Há de se ter claro que não é especificidade do campo estético "descrever" a realidade social (cf. Lukács 1965). Ao narrar, há de se enfatizar a dramaticidade da vida dos personagens, sob pena de se arriscar a organicidade do romance em cenas descritivas de paisagens não necessárias à sucessão dramática. Mas também não se trata de perder de vista as condições de vida que ligam a práxis dos personagens à vida íntima de seu tempo histórico. 
Devido a essa especificidade da fonte estética, o entendimento de Lins do Rego sobre o cangaço é indissociável da trama dos personagens. Os romancistas, exceção de um Victor Hugo, não abrem capítulos teóricos explicando, em termos abstratos, os enredos de seus próprios romances, ou as visões de mundo a partir das quais os desenvolveram. Por isso, o principal procedimento metodológico desta pesquisa consistiu em abstrair, nas narrativas estudadas, o contingente das relações socialmente objetivadas. Por exemplo, de dramas únicos, complexos e irrepetíveis sobre personagens de coronéis que auxiliam de alguma forma os cangaceiros em troca de favores, abstraíram-se as categorias do coito e dos serviços. Estas categorias, Lins não as expõe abstratamente em lugar algum das obras. Antes, elas se realizam na própria trama. Justamente por isso, pelo fato de que os personagens são os veículos destas categorias, não há como expor, separadamente, o cangaço na visão de Rego, deixando de lado os personagens dos cangaceiros. Assim, embora a tarefa de abstração tenha sido central ao momento da pesquisa, a exposição dos seus resultados, neste artigo, se faz de forma conjunta à apresentação de aspectos dos enredos de Pedra Bonita e Cangaceiros. Por tal motivo, no início da próxima seção, introduzi alguns elementos dos dois romances.

Para investigar como Rego se posicionava em face da teoria do banditismo social e da Escola Positiva, fontes de época contemporâneas ao romancista foram incorporadas. O mesmo se fez para intérpretes que vinculavam harmonicamente o cangaço ao coronelismo. Historiografia recente, especialmente as de Chandler, de Pericás e de Pernambucano de Mello, constitui importante aporte teórico de diálogo. A escolha de José Lins do Rego para o estudo do cangaço se deu em virtude de sua orientação estética pelo realismo regionalista de 30, cujo estilo expresso era narrar consubstanciando as condições de vida da sociedade nordestina da época.

\section{Cangaceiros:}

\section{Robin Hoods do Sertão ou agentes dos Coronéis?}

Os enredos de Pedra Bonita e Cangaceiros se passam em sequência narrativa na medida em que Cangaceiros segue contando a vida do personagem Antônio Bento, menino que, em Pedra Bonita, foi dado para criação ao padre Amâncio da vila de Açu, quando sua família se retirara, devido à seca de 1904, da pequena propriedade própria em que criava gado. A região em que se desenvolve o enredo de Pedra Bonita não é fruto da imaginação do romancista, mas local de existência real. Antes subordinada à comarca 
de Vila Bela, hoje a localidade da Pedra Bonita está compreendida pelo município de São José do Belmonte (IBGE 2017), próximo à Serra Talhada, em Pernambuco.

Antônio Bento, que volta a ter contato com sua família após o regresso dos retirantes, tinha dois irmãos: Domício e Aparício. Os dois rapazes, junto com o pai, o introspectivo Bentão, e sinhá Josefina, a mãe da família, compunham o núcleo familiar. Aparício seguiu o destino de seu avô paterno: o cangaço. Ingressou no grupo para se refugiar após assassinar um praça (Rego 2011c:188). Sua destreza no manuseio do rifle e na arte do comando o fariam ascender ao patamar de chefe de bando. A partir de então, sua família, por ser parente de cangaceiro, iria sofrer todo tipo de perseguição e represália por parte das tropas volantes. Domício representaria o outro lado do Sertão: se encantaria pelo fanatismo religioso, tornando-se assecla de um "Santo" que surgiria na região da Pedra Bonita (Rego 2011c:304). Daí o binômio sertanejo "cangaço-fanatismo" personificado nos dois irmãos de Antônio Bento.

A trama, em Cangaceiros, desce para a região de Tacaratu e de Jatobá, também no sertão do estado de Pernambuco. Antônio Bento e Sinhá Josefina saíram fugidos da Pedra Bonita quando tropas policiais, violentamente, desbarataram o arraial messiânico que na região se instalara e que arregimentara a família. Bentão já havia morrido. Domício, o irmão religioso, lutou a favor do "Santo" messias, matando soldados. Refugiou-se dos assassinatos no bando liderado pelo irmão Aparício. Na fuga do reduto, Aparício, que também apareceu por lá, ordenou a Bentinho que conduzisse a mãe ao engenho Roqueira, propriedade do velho Custódio, coiteiro com quem tinha relações (Rego 2011b:27).

O Nordeste brasileiro na Primeira República e, mesmo antes, no Segundo Império, viu se desenvolver o Coronelismo. Deve-se a Victor Nunes Leal $(2012,1980)$ e a José Murilo de Carvalho (1997) a percepção de que o coronelismo não foi mera continuação da hipertrofia do poder privado dos proprietários de terras, de seus mandonismos em paralelo à rarefação das instituições estatais, como ocorreria no Brasil Colônia. Ao contrário, o Estado aumentava sua presença pelo interior brasileiro. As antigas lutas entre famílias de patriarcas, existentes no Brasil colonial (cf. Costa Pinto 1949; Queiroz 1976:46), agora nesse novo contexto, tornavam-se disputas, muitas vezes armadas, pelo controle do Estado. Daí nasciam as concepções sertanejas dos jargões "estar por cima na política", "mandar no Estado" e ganhavam destaque as conhecidas fraudes eleitorais (cf. Telarolli 1982). As oligarquias que dominassem a máquina administrativa, policial e judicial do Estado teriam grandes benesses, sendo praticamente intocáveis por ela, 
além de disporem da mesma para reprimir os clãs adversários. Os mais fracos, agora, além de sofrerem nas mãos dos poderosos, pelejavam também com o Estado. Em paralelo, o Brasil mantinha a estrutura latifundiária colonial, que impedia grande parte da população de possuir terras.

Nesse contexto, surgiu a interpretação do cangaço enquanto banditismo social, da qual Rui Facó (2009), com Cangaceiros e Fanáticos, de 1963, foi o principal representante. ${ }^{6}$ Robin Hood da civilização do couro, o cangaceiro serviria para fazer justiça social, para desforrar o sertanejo pobre, o meeiro, o pequeno proprietário e o jornalista, que sofriam com a estrutura agrária latifundiária e com os mandos e desmandos dos coronéis, principalmente daqueles que dominassem as instituições do Estado. Essa leitura se tornaria mais consolidada a partir de apressadas incorporações, por parte da sociologia criminal brasileira, do livro Rebeldes Primitivos, de Hobsbawm (1983), cuja primeira edição de 1958 consolidou internacionalmente a teoria do banditismo social ao estudar bandoleiros em diversos países. ${ }^{7}$ No imaginário popular brasileiro e até em movimentos sociais, também se difundia essa percepção romântica sobre o cangaço: em 1959, "Francisco Julião, o líder das ligas camponesas de Pernambuco, [...] declarou que Lampião foi o primeiro a lutar contra os latifúndios e a injustiça dos poderosos" (Chandler 1981:268-269).

Como José Lins do Rego se posicionava diante dessa tese criminológica sobre a gênese do cangaço? Esta é a questão colocada nesta seção do artigo. Há de se começar a análise com algumas passagens em que o narrador coloca na boca de alguns personagens falas que endossam essa romantização do cangaço.

“Estou com pena de que se botem para as bandas do Ceará. Vão para o beato. Este nosso sertão é assim mesmo, senhora dona Josefina, há de sofrer com o governo, de rezar com o beato e lavar os peitos com os cangaceiros" (Rego 2011b:70), dizia o capitão Custódio, aquele coiteiro de Aparício. Ele teve o filho assassinado pelo coronel Cazuza Leutério, quando este "estava por cima na política". Custódio afirmava sofrer com o governo, o que significava, simbioticamente, padecer nas mãos do inimigo Leutério, já que este coronel dominava as instituições: "Ele [Cazuza Leutério] manda nas eleições e no júri. Ele manda no governo. Ele só não manda no vosso filho Aparício" (Rego 2011b:35). "O velho Custódio não tem proteção do governo e é capaz de aparecer força na fazenda e haver serviço feio" (Rego 2011b:229). Sua perspectiva de "fazer a justiça", de, como se dizia, "lavar os peitos", provinha de possível auxílio do cangaço: "Gosto de Aparício e sei que ele não faz mais do que tem que fazer um sertanejo de vergonha na cara. O governo é que é tirano" (Rego 2011b:32). 
Em Fogo Morto (1943) - livro que não faz parte do ciclo do cangaço, mas que merece atenção por também ter elementos sobre os bandoleiros sertanejos - o personagem José Amaro, artífice de engenho, representante, portanto, de classe inferior à de Custódio, foi expulso da casa onde morava no engenho Santa Fé após intriga com o senhor da terra, o seu Lula. Na estrutura social da época, era comum que os engenhos tivessem diversos tipos de artesãos, como marceneiros, oleiros e ferreiros, que viviam em sítios das terras dos senhores aos quais prestavam serviço. O ofício passava de pai para filho, assim como a moradia e as benesses que advinham dela: a principal, talvez, um pedaço de terra para plantar roça de subsistência. José Amaro, quando expulso da casa que seu pai erguera, refletia de forma similar a Custódio: o cangaço seria o único meio capaz de "dar direitos aos pobres" naquele interior da Paraíba.

E o tenente Maurício, por onde passava, era como um pé-de-vento, assombrando os homens, como aquele oficial do catorze, dos tempos do Quebra-Quilos, aquele de quem a sua mãe lhe falava como de um enviado do demônio. Ela lhe contava dos coletes-de-couro, das surras que o catorze dera por onde passava. Era assim aquele governo, era assim com tudo que tocava aos pequenos. Aquele Lula de Holanda, sem que nem mais, mandava que ele se fosse de uma casa que seu pai levantara. Anos e anos perdidos. E Manuel de Úrsula vinha lhe falar em direito. Pobre não tinha direito. Quem sabia dar direito aos pobres era o capitão [Antônio Silvino], era Jesuíno Brilhante, era o cangaço que vingava, que arrasava um safado como Quinca Napoleão (Rego 2009:305).

As falas do capitão Custódio e de José Amaro, um morador do Sertão e outro da várzea do rio Paraíba, se adéquam à teoria do banditismo social. E não seria ela correta? Afinal de contas, os cangaceiros não invadiam terras de coronéis, não lhes matavam os gados, queimavam as casas, destruíam as cercas? Também não saqueavam o cofre dos armazéns das cidades e deixavam os víveres para os populares? Esses atos, do ponto de vista de quem fora ultrajado por um coronel que posteriormente foi atacado por cangaceiros, não significam "fazer justiça"?

O mestre José Amaro, que nutria expectativa de justiça social para os pobres com a atuação de Antônio Silvino, ${ }^{8}$ porém, caiu em desconsolo ao perceber a existência de pactos entre cangaceiros e senhores de engenho. José Paulino, maior coronel da região, era amigo íntimo de Antônio Silvino e intercedeu a favor de seu Lula quando o cangaceiro entrara em sua casa em busca de moedas de ouro supostamente enterradas (Rego 2009:363-364): "O mestre José Amaro abalou-se [...]. Não era mais o homem firme, de minutos antes. O senhor de engenho podia até tomar a proteção do homem que ima- 
ginara como salvação dos pequenos [Antônio Silvino]" (Rego 2009:335). O artífice suicidar-se-ia ao final da trama.

O importante, aqui, é perceber que José Lins do Rego trabalhou em dois níveis: um sobre o cangaço na lenda popular; outro sobre o cangaço real, duas categorias que Billy Jaynes Chandler (1981), tempos mais tarde, foi astuto em distinguir. A lenda, por ser lenda, possui certa verdade. Muitos foram os casos, por exemplo, em que o cangaço foi refúgio contra perseguições de coronéis. Por vezes ainda, o exilado, após um tempo de "serviço", convencia o líder do bando a vingar-se do coronel que o oprimira. O cangaço, por fatos assim, era capaz de criar no imaginário popular uma representação de si enquanto justiceiro, enquanto capaz até, em nome dos oprimidos, de enfrentar coronéis. Mas essa representação do fenômeno é historicamente parcial. O cangaço, acidentalmente, fez suas justiças isoladas para alguns oprimidos, mas o seu modo de operar não estava em contradição com o "coronelismo", antes estava em perfeita sintonia: cangaço e coronelismo viviam em harmonia simbiótica. Pactos entre senhores de terras e cangaceiros, como o realizado entre José Paulino e Antônio Silvino, foram muito frequentes. O cangaceiro Balão, em depoimento ao historiador Frederico Pernambucano de Mello (2011:317), bem dizia que Lampião "não queria mudar nada". O cangaço era ajustado por demais ao coronelismo para ter pretensões de "justiça social" para os camponeses.

“- Sabe a senhora, essa gente aqui deste sertão não sabe quem é Aparício. Aqui em Tacaratu e Jatobá ele não põe os pés. O coronel Leutério tem força muita e tem gente no cangaço. E é por isso este povo anda gabando as façanhas de Aparício" (Rego 2011b:48). A personagem se enganou: não era Leutério, mas Custódio quem tinha gente no cangaço. Mas o que interessa é observar como o narrador utilizou essa personagem para veicular importante mensagem que distingue o cangaço real do lendário: conforme o coronel chefe da região fosse aliado ou não dos bandos de cangaceiros, a localidade estaria suscetível ou não às violências dos bandoleiros. E mais: quando as façanhas dos cangaceiros se realizavam contra coronéis (e suas gentes!) que fossem desafetos ou inimigos de determinados indivíduos ou comunidades, estes se gabariam das proezas. Elas virariam as lendas: o "inimigo de meu inimigo é meu amigo".

O local de atuação proeminente do cangaço foi o Sertão nordestino. Mas um cangaceiro em específico, sobretudo por atuar nas duas primeiras décadas do XX, e não mais tarde, como foi o caso de Lampião, se ambientou bem ao verde dos canaviais: Antônio Silvino. Tenho a impressão de que Rego conseguiu apreender as conexões entre os senhores de terra e os cangaceiros bem cedo, em virtude de fatos decorrentes de sua infância como menino 
de engenho. É preciso lembrar que Bubu, apelido carinhoso do avô de José Lins do Rego, era proprietário de sete engenhos em Pilar-PB. Esse poderoso senhor atendia pela alcunha de "padrinho" por Antônio Silvino. O cangaceiro, em episódio narrado em Meus Verdes Anos (1956), livro de memórias do romancista (Rego 2008b), quando soube de movimentação estranha de Cazuza Trombone, tio de José Lins, com alguns de seus inimigos, foi ao chefe do clã passar a limpo a história. ${ }^{9}$

- Tive a notícia de que o coroné Trombone estava de combinação com os meus inimigos. Até disse ao sujeito que me fazia intriga: "Pois não acredito. Basta que o coroné seja genro do meu padrinho do Corredor. [...]". Antônio Silvino viera como amigo. Meses antes atacara a vila do Pilar para se vingar de Quinca Napoleão. Não encontrando o comerciante, arrasou o estabelecimento (Rego 2008b:168).

E reatando a "amizade", Antônio Silvino pediu a Bubu um boi de raça para dar cria. Esse Robin Hood tinha para mais de mil cabeças de gado em fazendas de coronéis amigos. ${ }^{10}$

Agora estavam amigos outra vez. [...]. Havia meu avô comprado da Índia um casal de bois. [...]. Antônio Silvino demorou-se na admiração dos zebus, os primeiros que haviam aparecido no norte do Brasil. E pediu uma cria a meu avô. [...]. - É boi e tanto, meu padrinho! - E pôs-se a falar do gado que tinha no sertão. Tinha para mais de mil cabeças espalhadas em fazendas de amigos (Rego 2008b:180).

José Lins do Rego, enfim, narrou o imaginário romântico que permeava as façanhas dos bandoleiros sertanejos. Colocou a lenda na boca de alguns personagens, como o capitão Custódio e o mestre José Amaro, e os cantadores e trovadores. Mas além da lenda, que a teoria do banditismo social transformou em conceito do cangaço, Rego também investigou as entranhas da conexão real entre os cangaceiros e os coronéis.

\section{Troca de favores entre coronéis e cangaceiros: coito x serviços}

José Lins do Rego adentrou nas determinações específicas da relação entre os coronéis e os cangaceiros: a troca de favores através do coito e dos serviços. Pelo epíteto de coiteiros, atendiam os coronéis que se serviam, de algum modo, de suas propriedades em benefício dos bandos. A espécie de coito que aparece mais habitualmente na obra de José Lins do Rego é o coito de pouso ou coito de pernoite, em que os cangaceiros faziam uso das propriedades para repouso, especialmente durante o período noturno. 
Mas há outras modalidades reproduzidas pelo romancista. O coito de tratamento ou de ferimento ocorria quando algum bandoleiro doente ou ferido em combate se convalescia nas terras do coronel. Vicente, cangaceiro do alto escalão do bando de Aparício, por exemplo, se restabeleceu no engenho do capitão Custódio, o Roqueira (Rego 2011b:207), calculo eu, por um ou dois meses. Notam-se também os coronéis coiteiros de munição, que guardavam as balas de fuzil que os cangaceiros adquiriam, ou mesmo que negociavam os produtos com os chefes dos bandos. O personagem do major Sindulfo foi um desses coiteiros. Formou até filho doutor com dinheiro da venda de cartuchos: ${ }^{11}$ "as balas vendidas a Aparício, para o cangaço, deviam-lhe render muito. [...]. Cada bala desta está custando um dinheirão. O major Sindulfo, de Bom Conselho, não quer outra vida. É só comendo dinheiro de Aparício" (Rego 2011b:154-156).

Rego narrou também a modalidade de coito de descanso, dos tempos em que o bando saía do puxado em semanas de repouso. ${ }^{12}$ A situação narrada abaixo cumula o descanso com a convalescença.

Tinham estado em descanso na fazenda do coronel Carvalho, em Sergipe, para mais de três semanas. Aparício teve um panarício no dedo e veio inté o filho do coronel, que era doutor, para curar do tumor. Rasgou o dedo do capitão e ele nem deu um gemido. Felizmente isto foi coisa, lá nele, na mão esquerda. A força do Sergipe nem deu pelo fato. Andava nas caatingas da Bahia atrás de Aparício. Mas o coronel Carvalho manda no governo e não há volante que entre em sua propriedade (Rego 2011b:258).

Em troca das diversas modalidades de coito, os cangaceiros realizavam os serviços contra os inimigos dos coiteiros. "O cangaço tem compromisso com seus coiteiros, seus amigos - a lealdade tem reciprocidade" (Shaker 1979:86). Dessa forma, o cangaço se inseria na lógica das disputas entre proprietários de terra, do coronelismo: "Aparício estava de ajuste com o coronel Fonseca para liquidar inimigo dele. E era ajuste que não podia demorar muito. Tinha vindo um mandado para fazer o serviço com rapidez" (Rego 2011b:74). Esta era a esperança de Custódio: de Aparício lhe prestar um serviço contra Cazuza Leutério, em troca do coito às suas munições, à convalescença do baleado Vicente e à proteção da mãe Josefina. Aliás, esta última modalidade de coito já iria passar despercebida à exposição: o coito de proteção aos parentes dos cangaceiros, que requeria muito sigilo, investida em novas identidades pelos protegidos e invenções de estórias aos demais viventes da propriedade do coiteiro.

Alguns relatos da época de Lins, às vezes reproduzidos mesmo em jornais, davam notícia dos já famosos serviços prestados pelos cangaceiros aos coronéis. O próprio Lampião (citado em Pernambucano de Mello 2011:118), 
em entrevista ao jornal O Ceará, de 17 de março de 1926, dizia: "- Foi o coronel José Pereira Lima, chefe político de Princesa, homem perverso, falso e desonesto a quem durante anos servi, prestando os mais vantajosos favores da nossa profissão". O padre José Kherle (citado em Pernambucano de Mello 2011:317), que mantinha amizade com Lampião e o confessava, disse certa vez: "Lampião sempre foi protegido por chefes políticos e grandes donos de terras. Deles, em troca de determinados 'serviços', Lampião recebia armas e mantimentos".

De posse desses relatos, nos anos 30, quando da escrita de Pedra Bonita, amadurecia a teoria que percebia o cangaço como banditismo que convivia em harmonia com o coronelismo. Em 1936, o jurista Roberto Lyra, por exemplo, demarcou bem sua posição acerca da " [...] tragica e horrenda symbiose do coronelismo com o cangaceirismo [...]. Assim como os 'intrujões' não pódem medrar os ladrões, não seria possivel o cangaceirismo sem o 'coronelismo', que o mantem e delle se serve, sem os coiteiros" (Lyra 1936:574-576). Outro romancista da literatura nordestina de 30, José Américo de Almeida, escreveu no romance Coiteiros, de 1935: "- Há muitos coiteiros... - No geral, protegem. Uns por medo; outros por interesse. Uns por vingança; outros por dinheiro. Fora à parte, os políticos. [...]. Naquelas paragens, um cangaceiro era o melhor aliado. Não atacava e defendia dos inimigos" (Almeida 2008:170-171).

Ao menos a partir de 30, portanto, é possível verificar a cisão de duas vertentes teóricas contrastantes na interpretação acerca do cangaço: a do banditismo social, que concebia o cangaço como meio de fazer justiça contra os coronéis; e a da simbiose entre cangaço e coronelismo, que entendia os dois fenômenos em harmonia. Como temos visto, Rego partilhava desta segunda concepção. Mas nem sempre os teóricos da época conseguiam separar bem os dois entendimentos. Este é o caso do eclético jurista Magalhães Drummond que, embora vinculasse os dois fenômenos - banditismo e coronelismo - e até discorresse sobre as lutas de famílias, também enxergou no cangaço a dimensão de "justiça social", do bandido como reação contra coronel.

E ainda não há muito tempo telegramas do Norte do Brasil davam notícias da iminência de um sério encontro entre duas poderosas famílias em luta antiga, e de que participariam numerosos partidários de uma e doutra, por elas armados e postos em pé de guerra, para um combate decisivo, em que se empenharam centenas de combatentes. [...]. Numa grande parte do Brasil-interior, quem não se quiser conformar com a sua própria escravização aos caciques políticos, aos "grãos-senhores de taba", aos mandões municipais ou regionais, tera, muita 
vez, de se fazer também chefe de bando, e, segundo a judiciosa observação de Afrânio Peixoto, o "bando é que faz o bandido". [...]. Porque há, mesmo em Minas, lugares, felizmente hoje raros, nos quais ainda troveja e domina, onipotente e estentórico, ronco do coronelão [...]. Sob uma tal dominação - brutal e estúpida -, homem de condição humilde, mas digno e combativo, é muita vez arrastado a uma reação violenta. Medroso de que venha a faltar liberdade ao Juri para julgar com justiça, sonega-se ao julgamento, fugindo dos povoados e homisiando-se em lugares mais dificilmente accessíveis à polícia. [...]. Para poder viver, terá de viver do crime. A êle juntam-se em breve outros perseguidos da justiça, e assim se forma o bando, e assim começa a nascer outro poder ilegal no sertão. [...]. O mandonismo e o banditismo, formas diversas de um mesmo mal, esta mais visível, aquela mais constante, somente serão combatidos por um trabalho sincero de civilização do Brasil-interior (Magalhães Drummond 1944:189-191).

\section{De “capangas" e "jagunços" a cangaceiros}

A visão de mundo de José Lins do Rego era cheia de tensões (cf. Peregrino 2013). Embora não deixasse de ressaltar as virtudes que ele enxergava no mundo patriarcal dos engenhos na época colonial, preferindo-o à modernização advinda com a usina e com o Estado de Direito - assunto que não posso tratar dentro do objeto deste trabalho por estar mais adstrito ao "Ciclo da cana-de-açúcar" - o romancista não se furtou de admitir mazelas do mandonismo dos senhores de terras. Estamos diante de um desses momentos ao analisar um artigo de 1957, quatro anos após a publicação de Cangaceiros, em que José Lins do Rego diagnosticou a origem do cangaço nos grupos de apaniguados, capangas e jagunços que se juntavam em torno dos clãs patriarcais desde a Colônia.

A história do cangaço, no Nordeste brasileiro, está intimamente ligada á história social do patriarcalismo, á vida de uma região dominada pelo mandonismo do senhor das terras e de homens, como se fôssem barões dos feudos. O chefe que mandava, de baraço e cutelo de família, nos aderentes, nos eleitores, precisava muitas vezes de fôrça, acima da lei, para impor-se e dominar sem limites. Nem o Estado seria capaz de enfrentar o chefe que, no sertão, era mais que o Estado. Para manter-se de pé, prefirmar-se suseranamente, o chefe recorria a seus homens dispostos, as cabras de ôlho virado, aos que matavam sem dor na consciência. A função do cangaceiro passava a ser uma espécie de gendarmeria às avessas. $\mathrm{O}$ crime é que tinha poder corretivo. Assim surgiram cangaceiros que, revoltando-se contra o chefe, fizeram trabalhar por sua conta, a serem êles próprios os que ditassem lei no sertão. Armados pelo "coronel" passaram a dar cartas, a casar, a descasar, a dividir terras, a exercer pelo trabuco o govêrno das caatingas (Rego 1957:31). 
Cangaceiros e coronéis, na literatura de José Lins do Rego, como temos visto, conviviam em simbiótica harmonia na República. Mas, com esse artigo de 1957, nota-se que, para Rego, essa ligação remonta também a uma origem histórica entrelaçada: o cangaço teria sua gênese histórica no patriarcalismo colonial. Os senhores proprietários, na Colônia, dispunham de séquito de capangas e jagunços. Estes eram, em regra, homens livres que moravam nas propriedades dos senhores e que lhes deviam lealdade em troca de pedaços de terras destinados a eles para cultivo próprio. No coronelismo, há cissiparidade e "profissionalização do serviço" em bandos de cangaceiros autônomos, que continuavam a prestar os serviços armados, mas a quem melhor lhes pagasse, fosse em pecúnia ou coito, e não sedentariamente a um único senhor.

É possível remontar essa ideia sobre a gênese histórica do cangaço a autores dos anos 30. Djacir Menezes, em texto cuja primeira edição data de 1936, foi quem primeiro utilizou o termo "cissiparidade" para designar a autonomização do jagunço em relação ao coronel, fazendo surgir o cangaceiro. ${ }^{13}$ Talvez Djacir Menezes tenha influenciado José Lins do Rego. Quando Gilberto Freyre (1967:XI) fez o seu Nordeste, em 1937, dizia existirem ao menos dois Nordestes, o agrário da cana-de-açúcar e o pastoril do gado. O historiador pernambucano dissertou acerca do canavieiro e, na qualidade de editor da José Olympio, influenciou Djacir Menezes na escolha do título de sua obra como O outro Nordeste, aquele pecuário da civilização do couro (cf. Menezes 1970:13). No intervalo de um ano, publicaram-se o Nordeste e O outro Nordeste. Sabendo que Freyre era mentor de Lins no "Ciclo da cana-de-açúcar", considero também que Menezes, por circular pelos mesmos círculos intelectuais, possa ter contribuído com o "ciclo do cangaço".

A tese da cissiparidade ainda tem gozado de prestígio em tempos mais contemporâneos. ${ }^{14}$ A historiadora Maria Isaura Pereira Queiroz, por exemplo, afirmava que o "cangaço se origina fundamentalmente ligado às lutas de família e de parentelas no Nordeste brasileiro; o aparecimento do cangaço independente não corta estes vínculos, mas os prolonga" (Queiroz 1977:206). A separação entre cangaceiro, antigo jagunço ou capanga, e coronel foi somente espacial, embora se mantivessem as relações de trocas de favores. Por isso, nos dizeres de Queiroz, os vínculos não se cortaram, antes, se prolongaram. Em suma, a violência armada que os jagunços praticavam em razão de lealdade ao patriarca, agora, na República, era colocada no mercado com o coronelismo e com o cangaceirismo. 
"Cangaço vingança”, "cangaço refúgio", “cangaço meio de vida” e "cangaço como destino de família"

Além de uma exposição das condições objetivas do surgimento do cangaço - as lutas de famílias e as disputas políticas entre os coronéis - José Lins do Rego se preocupou também em narrar as motivações individuais e imediatas pelas quais cada sujeito resolvia ingressar nos grupos de bandoleiros. Frederico Pernambucano de Mello (2011), recentemente, fez o mesmo trabalho ao categorizar tais motivações em três grupos, que denominou como cangaço vingança; cangaço refúgio e cangaço meio de vida. Ao que se pode perceber das fontes pesquisadas, estes três tipos de motivações também foram diagnosticados pelo romancista.

O cangaço refúgio tem as já expostas histórias individuais de Aparício e de Domício como principais representantes. Aparício, em uma farra de feira, assassinou um praça e debandou para o cangaço (Rego 2011c:188). Domício, para proteger um Santo, percorreu o mesmo destino (Rego 2011c:304). Este tipo de motivação, portanto, tinha como finalidade escapar do alcance da polícia e da justiça, mas também de inimigos coronéis que almejassem algum tipo de vingança. Na passagem acerca do jovem Anacleto está explícita a função cangaço enquanto o refúgio.

- O meu filho Anacleto, depois que foi se perder em Jatobá, caiu no cangaço e anda no bando de Aparício [...]. Este cabra tem desgraçado o sertão e botado a perder os filhos da gente. Anacleto era um bom rapaz. Fez só aquela besteira de Jatobá. Podia ter ido para o júri e lá o coronel Cazuza livrava ele. Mas não. Foi para o desgraçado Aparício (Rego 2011b:40).

O cangaço vingança significava adentrar nas fileiras dos bandos com a finalidade de assassinar inimigo que lhe infligira danos. Sem perspectiva de contar com o Estado, ou com coronel mais forte que o violentador, o sujeito buscava o cangaço para se vingar. ${ }^{15}$ Com bons serviços prestados, após algum tempo de cangaço, poderia ter o "trabalho" recompensado quando o chefe conduzisse os asseclas na execução de seus planos de represália. No enredo de Cangaceiros, Germano, o que seria chamado "Corisco", se alistou no séquito de Aparício objetivando retaliar comandante de tropa volante que arruinara sua família.

Uma vez, passou pelo sítio onde ele morava o capitão Aparício Vieira. Deulhes coalhada e tratou-os como se trata uma visita de cerimônia. Pois bem, não demorou muito e bateu por lá a força do tenente Lopes, homem também natural de Vila Bela: "Pegaram o velho meu pai e foram com ele ao cipó de boi. 
Amarraram ele na prensa da casa de farinha e foi um dar de cortar o coração. Eu e Germano já estávamos no meio dos praças. Germano ainda quis se fazer na faca e levou uma coronhada de rifle que pegou, lá nele, bem no pé do ouvido. As minhas irmãs deram para chorar e eu vi o desgraçado dum praça apalpando uma delas como se fosse galinha. Pulei pra cima do cabra e nem sei contar o que aconteceu. Veja esta marca de talho, aqui na testa. Fizeram o diabo nas moças bem na nossa cara. Levaram o velho para Vila Bela, estragaram as moças minhas irmãs e foram dando no velho até na cadeia. Deixaram a gente naquela miséria. Só sei que dois dias depois bateu na nossa casa a notícia: o velho tinha morrido. [...]. E nunca mais eu vi Germano arreganhar os dentes para sorrir. [...]. Ele me diz todo dia que só descansa quando cair no grupo de Aparício Vieira (Rego 2011b:51-52).

Já o jovem cangaceiro Cobra Verde não tinha contas a acertar com comandante de tropa, mas com vizinho Zé de Paula, proprietário que, em disputas por terras, usou de sua influência sobre os "mata cachorros", ou "macacos" - termos usados para as tropas estatais, em contraste com as tropas de linha, do exército - para assassinar seu pai. A rompante desforra do menino foi memorável: "Não ficou nem as galinhas, no poleiro. Cobra Verde sangrou o velho Zé de Paula e fez até precisão na cara do defunto estendido no meio de mulher e das filhas mortas. O menino saiu para fora e matou tudo: os bois, os cavalos, até os cachorros. E tocou fogo na casa". Agora sertanejo de honra familiar lavada, no dia seguinte à vingança, o jovem disse a Aparício: "Capitão, eu já posso morrer. A minha mãe me pediu vingança e eu dei a vingança" (Rego 2011b:65). A vingança também era motivo para o sertanejo, como diziam, "sentar praça", ou seja, tornar-se soldado em tropa volante. Mas, neste caso, o inimigo perseguido, provavelmente, seria algum cangaceiro. Este foi o caso de outro personagem com mesmo nome "Anacleto", cujas filhas foram abusadas por cangaceiros de Aparício (Rego 2011b:77-78).

O romancista e o historiador Frederico Pernambucano de Mello também se aproximaram ao explorar o chamado cangaço meio de vida, em que os sujeitos tinham tão somente a perspectiva de auferir riquezas com o cangaço. O personagem "negro Vicente", subcomandante e compadre de Aparício, seria um representante desta espécie de cangaço. Após fazer serviços para alguns coronéis como jagunço de emboscadas, Vicente almejava permanecer neste tipo de "trabalho", até que entrou no cangaço sob o comando de Luiz Padre (Rego 2011b:216, 227-228). Neste caso, o cangaço não se reveste de vingança ou refúgio. É tão somente a profissão, meio de ganhar a vida. 
José Lins do Rego explorou uma categoria adicional às propostas por Frederico Pernambucano de Mello, ou talvez fosse uma subespécie do cangaço refúgio, que é o cangaço como destino de família. Ela ocorria, na literatura do romancista, com os parentes de cangaceiros que, violentados frequentemente pela polícia, acabariam por cair no cangaço por falta de alternativas. "- Germano foi para o Cangaço, e agora que sou irmão de cangaceiro, vai começar o meu sofrer com os soldados. Com pouco todo mundo vai saber. E a gente se aperreia tanto que só vai descansar quando cair também no cangaço" (Rego 2011b:93).

\section{A astúcia antropológica de José Lins do Rego}

Rego não esposava as teorias Robin Hood. Agora, resta-nos analisar como o romancista lidava com a explicação do cangaço realizada pela Escola Positiva.

Fundada na Itália no último quarto do século XIX por Cesare Lombroso, Enrico Ferri e Rafaelle Garofalo, a Escola criminológica Positiva entrelaçava estudos em medicina forense, direito penal e antropologia. Ela listava, de forma supostamente científica, características psíquicas e antropomórficas que seriam capazes de identificar seres humanos atavicamente criminosos. De uma série de medidas de partes do corpo humano e de análises do comportamento, a Escola Positiva diferenciava o homem contemporâneo daqueles que constituíam os povos selvagens e bárbaros, sendo o primeiro mais bem desenvolvido que estes. Além disso, dos homens que viviam na "civilização", alguns não teriam atingido o amadurecimento de todos os caracteres físicos e morais do "homem civilizado", sendo ainda similares aos selvagens e bárbaros. De sensibilidade apaixonada, esse selvagem vivente da civilização seria incapaz de se adaptar ao direito penal moderno: é de sua natureza ser delinquente. Dois problemas em um só: um antropológico, por analisarem povos antigos enviesadamente, com os parâmetros da sociedade contemporânea, outro em criar estereótipos de "criminosos hereditariamente natos". Nas palavras de Lombroso (2010:126): "Muito mais que aos dementes, o delinquente, em relação à sensibilidade e às paixões, avizinha-se aos selvagens. Também a sensibilidade moral é abrandada ou anulada nos selvagens".

Esses seres humanos civilizados supostamente pouco desenvolvidos padeceriam de uma compulsividade criminal dada pelas paixões que eles, tais como os povos selvagens, não conseguiriam controlar. Entregues aos prazeres, faltaria a eles a razão, freio à sensibilidade. Mas não lhes seria 
facultado aprender o convívio "racional da civilização moderna", posto que, atavicamente, os criminosos natos não disporiam, assim como supostamente não dispunham os homens selvagens, orgânica e moralmente, de aparelhos necessários para tanto. O problema é genético.

Estava pronto o instrumental "científico" para algum antropólogo brasileiro analisar o cangaço, ${ }_{16}^{16}$ bastava importá-lo, decapitar alguns cangaceiros para análise métrica de seus crânios e pronto: "Soube que é homem disposto. Liquide todo criminoso nato" (Pernambucano de Mello 2011:264), determinou o governador do Ceará Benjamin Barroso a um tenente comandante de tropas volantes, referindo-se a cangaceiros. O Brasil, aliás, devido à formação colonial, que colocou em contato povos culturalmente distintos europeus, ameríndios e africanos - foi terreno fértil para a adoção das ideias lombrosianas. ${ }^{17}$ Nina Rodrigues (2010:300-301), médico brasileiro discípulo de Lombroso, hierarquizava o desenvolvimento moral e jurídico das "raças brasileiras" à moda da Escola Positiva italiana.

E, no Brasil, ainda havia o problema do "mestiço", muitas vezes apontado como um degenerado em conflito interno por herdar aparelhos morais diversos, de humanos selvagens e outros civilizados. Na análise de Nina Rodrigues (1957:144-145): "A indolência, a apatia, a imprevidência, todos os maus predicados [...] fàcilmente podem ser descobertos nos mestiços de todo o país". Euclides da Cunha (2014:190), outro representante dessas teorias raciais em que se embebia a antropologia criminal, falava em desequilíbrio nervoso incurável do mestiço. ${ }^{18}$ A mestiçagem era, aos olhos dessa escola criminológica, um agravante ao cangaceiro e, de modo geral, ao sertanejo, povo, em sua maioria, mameluco.

Porém, o cangaceiro, obstinado que enfrentava força volante e tropa de linha; que carregava por volta de $20 \mathrm{~kg}$ nas costas em andanças diárias de léguas e léguas; que, de rifle Winchester ou de fuzil Mauser, padecia com as novas armas dos "macacos" - fuzil metralhadora Hotchkiss modelo 1921, submetralhadora Bergmann, de 1934 etc. (Pericás 2010:84) - não se deixaria vencer por qualquer pseudociência. Artur Ramos se surpreendeu com Volta Seca: crânio perfeito para o padrão do "homem civilizado" (Pericás 2010:128). ${ }^{19} \mathrm{O}$ último assassinato Lampião cometeu quando já estava morto. O governador do Sertão matou a antropologia criminal, brincou o historiador Frederico Pernambucano de Mello (2011:329): ao ter seu crânio analisado pelos médicos criminalistas, estes não encontrarem nenhuma anormalidade. Mesmo se apresentasse, não validaria a "ciência" de Lombroso. Quanto ao "Rifle de Ouro", Graciliano Ramos, ao visitá-lo na prisão, em companhia de José Lins do Rego, desenganou-se da imagem criada pelos "médicos" que pretendiam fazer dos infelizes negros e mestiços "raças" inferiores ou degeneradas: para sua surpresa, Antônio Silvino era branco e alto. ${ }^{20}$ 
Lombroso (2010:206) falava da "preguiça" dos criminosos e dos povos selvagens. Em Riacho Doce (1939), livro que não pertencente a nenhum dos dois ciclos de romances de Rego e que se ambienta no litoral nordestino, quando um engenheiro quis assalariar o trabalho dos pescadores, empregando-os na indústria do petróleo e mudando os seus modos de vida, recebeu resistência: "O engenheiro era um homem alto, de olhos verdes. Morava com a mulher, uma americana, na casa que fora do governador. Vivia de botas, andando para cima e para baixo, dando ordens. Chamava todos eles de preguiçosos, de indolentes. Só mesmo à força eles saberiam o que era trabalho" (Rego 2011d:118). A astúcia antropológica de José Lins do Rego compreendia que, diante do modo de vida extrativista e da produção coletiva dos praieiros, o trabalho assalariado não seria aceito sem resistência, nem mesmo seria sedutor. Em artigo publicado em 1942, três anos após a publicação de Riacho Doce, o romancista explicitou o substrato antropológico por trás do romance e acentuou a crítica contra a visão do personagem engenheiro, que era a mesma defendida, entre outros, por Euclides da Cunha:

Euclides da Cunha falou dos "mestiços neurastêmicos do litoral", de "raquitismo exaustivo". Nada mais falso, nenhum julgamento feito com base segura na realidade. Os praieiros são sempre senhores de si, dominados, pacientes, sem pressa, os homens menos fanáticos do nordeste. É preciso conhecê-los no seu habitat, conhecê-los, sondar-lhes a vida e os seus meios de trabalho, as suas preocupações, os seus contatos com a natureza. [...] a tal preguiça praieira não passa de falsidade. São homens que se entregam à pescaria com uma paciência e uma luta de titãs. Essa é que é a verdade. Um curioso que chega de longe e encontra homens espichados ou debaixo das caiçaras tira logo a conclusão apressada: gente preguiçosa. Não sabe que muitos daqueles estiveram noite inteira na jangada, balançando nas ondas atrás das ciobas, das cavalas, horas e horas, dia e noite na luta pela vida (Rego 2004:244-245).

É preciso conhecer o caiçara em seu habitat, afirmava Rego criticamente a Euclides. Ao questionar Euclides da Cunha, Rego enfrentava um gigante: nada menos que o fundador da sociologia criminal no Brasil, segundo a opinião de Roberto Lyra (1974:88), jurista contemporâneo do romancista. E, contra o mesmo Euclides, José Lins do Rego, em outro artigo de 1942, repreendia-o pelo modo como concebia o homem mestiço do Sertão nordestino.

A minha última viagem ao Nordeste deu-me a oportunidade de observar o sertanejo transformado pelas obras contra a seca. Euclides falara do homem "desengonçado e torto", de um homem feio e triste. Euclides tinha para tudo que via um olho de Goya. [...]. No fim, um monstro, refletindo "a preguiça 
invencível, a atonia muscular perene, em tudo: na palavra moderada, no gesto contrafeito, no andar desprumado". Não era "possível idear-se cavaleiro mais chucro e deselegante". Esse exagero de traços, essa deformação de linhas ganharam fama de retrato fiel. E, no entanto, este sertanejo de Euclides era mais uma ficção do gênio criador, era mais o homem da imaginação do poeta que o homem verdadeiro dos nossos sertões nordestinos. Euclides fora encontrar o sertanejo alterado, fora de si; homens incendiados pelo fanatismo, populações sob o terror de uma guerra. Nada mais ao seu gosto de pesquisador de tragédias (Rego 2004:261-262).

Esta passagem de Rego lembra muito o relato de seu amigo Gilberto Freyre (2003), presente na introdução de Casa-Grande \& Senzala, sobre como o impressionou a imagem da atonia muscular de marinheiros mulatos da corveta São Paulo. Freyre explicaria o caminho antropológico que faria para não identificar nessa compleição física débil as teorias científicas dos "médicos". Parece clara a contribuição de Freyre para as concepções raciais do amigo romancista, que igualmente rechaçava a antropologia médica. Assim como os praieiros, seria preciso, na análise dos sertanejos realizada por José Lins do Rego, "conhecê-los no seu habitat, conhecê-los, sondar-lhes a vida e os seus meios de trabalho, as suas preocupações, os seus contatos com a natureza" (Rego 2004:244). A terra e o homem mandavam em seus romances. Seus cangaceiros tinham a explicação dada não por preconceitos cientificizados contra o sertanejo. Explicavam-se pelo coronelismo, pelas vinganças privadas, pela violência policial, enfim, pelas condições objetivas e pelas motivações individuais que impeliam os indivíduos aos grupos de bandidos. O crime não era hereditariamente irresistível, tinha explicação social. Os personagens cangaceiros eram cruéis, sádicos e sanguinolentos, como realmente foram, mas eram complexamente humanos e não atávicas bestas.

Termino com o humanismo de José Lins ao criar Domício, a meu ver, o maior personagem de toda a sua obra, que se desgraçou primeiro com o "Santo" e depois com o cangaço. Em Pedra Bonita botava a viola a gemer. Na melhor moda dos cantadores nordestinos, contava a própria sorte.

[Domício] [n]ão tinha vontade de entrar para o cangaço. Muitos tinham ido para lá sem querer, levados pela perseguição [à família de cangaceiros]. Mas ele não iria. Só iria no fim de tudo. A viola estava dependurada. Era o seu consolo. Há quase uma semana não pegava nela. E tirou-a do saco de algodãozinho e começou a pinicar na companheira. Estava só. Ninguém ouviria o que ele cantasse. Então Domício começou a falar de Aparício. A contar a história do cerco de Araçá. O pai e a mãe tinham apanhado [da polícia] de cipó de boi. O irmão tivera a cara cortada pelo chicote. Ele tinha ido para a cadeia de Dores, e 
Aparício, no rifle, solto na caatinga. E Aparício no bando, de rosário no pescoço, chorando a desgraça do pai e da mãe. Aí o cangaceiro pensou em se vingar. E foi o tiroteio do lajedo. Morreu tudo que foi praça. A terra ficou molhada de sangue. Duas horas lutaram, os cabras atrás das pedras e os soldados no raso. A viola gemia, Domício gemia. Morreu tudo (Rego 2011c:218).

Em Cangaceiros não havia mais viola, só o fuzil, e a saudade.

Bentinho e Domício fecharam-se no silêncio de quem tinha uma dor comum, uma mesma saudade. O silêncio daquele retiro, na noite, doeu-lhes nos corações partidos de mágoa. Foi Domício quem primeiro falou: - Bento, eu fico neste paradeiro e o que me vem na cabeça é uma coisa só. É o Araticum com a gente menino, com pai, com mãe, com as tristezas. Eu fico a imaginar no destino do nosso povo. Tu não pensa que o cangaço me secou o coração todo. Eu sei que perdi tudo, que nem posso mais abrir a boca para contar. Sim, mano, tudo passou, tudo se acabou. Mas se estou assim como agora, entra uma coisa dentro de mim, me entra no corpo e me esfria todo. Vê tu que não é fraqueza, que não é medo de morrer. Não é não. Morrer já podia ter morrido, quantas vezes, não é medo não. É uma coisa parecida com um não sei o quê. Quando estava com Aparício, na caatinga, me chegava de quando em vez esta mesma coisa. A gente parava por debaixo de um pé de imburana para deixar o sol correr mundo. Eu me espichava por cima das folhas secas. Até os bichos do sertão tinham fugido daquele braseiro. E não cantava nem um passarinho, era só o tinir do sol na caatinga. Aí, menino, se dava o negócio. Vinha por cima de mim uma coisa assim como se fosse um frio. O coração batia mais depressa e eu só tinha uma vontade. Era de abrir a boca no mundo e cantar o que eu sabia, o que estava escondido nas profundezas. Queria cantar e não podia. Queria sentir outra vez, no corpo, aquela agonia dos outros tempos e não podia. Ah, Bentinho, tu não sabe o que é sofrer! (Rego 2011b:172).

\section{Conclusões: o cangaço de José Lins do Rego}

Quando José Lins do Rego compôs os romances Pedra Bonita (1938) e Cangaceiros (1953) que, em conjunto, formam o chamado "Ciclo do cangaço, misticismo e seca", já estava relativamente consolidada a teoria do banditismo social, que entendia o cangaço como reação contra a estrutura agrária latifundiária brasileira e contra os mandos e desmandos do coronelismo. Os cangaceiros seriam bandidos sociais que desforravam os sertanejos pobres das injustiças sofridas. Esta pesquisa percebeu que o romance de Rego 
superou essa lendária explicação do cangaço, embora coloque nas falas de alguns personagens tal imaginário romântico. O cangaço não era, na visão de José Lins do Rego, instrumento de enfrentamento ao coronelismo. Pelo contrário, ambos conviviam harmonicamente. Trocas de favores na relação coito x serviços conferiam simbiose entre cangaço e coronelismo. É possível até, na visão de Rego, remontar os dois fenômenos a uma origem histórica entrelaçada dada pelo patriarcalismo colonial. Neste, os senhores mantinham relações de lealdade com capangas moradores de suas propriedades que, em troca do uso das terras em proveito próprio, constituíam-lhes espécies de exércitos privados. Com a República, os capangas viraram bandidos independentes. Os laços entre os bandoleiros e os proprietários de terras se mantêm, muito embora, agora, estejam colocados no mercado: os cangaceiros servem a quem melhor paga, em pecúnia ou em coito, e não fixamente a um único senhor.

Mas isto não significa afirmar que os bandidos, para Rego, fossem bestas atavicamente criminosas. Também na época da escrita dos livros sertanejos do romancista, a Escola criminológica Positiva brasileira tinha esta percepção: a de que os cangaceiros seriam criminosos natos, com especial razão devido à origem racial mestiça do povo sertanejo. Médicos do instituto Nina Rodrigues analisavam em vão crânios de Lampião e de outros cangaceiros em busca de caracteres indicativos de desvios biológicos para o crime. O romancista, porém, explicitava, em artigos, sua crítica a essa escola. Seus personagens cangaceiros não são bestas. Podem ser cruéis, muito cruéis, mas são humanos. A explicação do cangaço não passa pela biologia, mas pelas relações sociais dadas pelo Sertão coronelista.

Recebido em: 02 de abril de 2019

Aprovado em: 23 de julho de 2019

João Paulo Mansur é doutorando e mestre em Direito pela Universidade Federal de Minas Gerais. Graduado em Direito e graduando em Ciências Sociais pela Universidade Federal do Espírito Santo. Membro do Studium Iuris, Grupo de Pesquisa em História do Direito (UFMG). Desenvolve pesquisas em história sociojurídica, com foco nos temas "cangaço", "coronelismo" e "patriarcalismo" no Brasil.

ORCID https://orcid.org/0000-0002-5849-992X

E-mail: jpmansur@gmail.com 
Agradeço às valiosíssimas críticas de Ricardo Sontag, Ivan Vellasco e Vitor Sartori. Agradeço também às contribuições dos avaliadores e editores da revista Mana. Este trabalho foi formulado a partir de minha dissertação de mestrado, Aos amigos o direito; aos inimigos a lei: Mandonismo, Coronelismo, Júri e Cangaço na literatura de José Lins do Rego, que contou com financiamento da Capes.

\section{Notas}

1 Edições consultadas dessas obras foram (Rego 1977, 2008c, 2009, 2011a,2012b e 2012d).

2 Esta passagem não deve ser entendida como manifestação de adesão a um rudimentar naturalismo. A "terra", para Rego, não é autarquia separada dos dramas tipicamente humanos.

3 Além das obras que compõem os dois ciclos, José Lins do Rego escreveu outros quatro romances: Pureza, de 1937, Riacho Doce, de 1939, Água-Mãe, de 1941, e Eurídice, de 1947. São obras independentes por não possuírem união em torno de uma temática central. Edições consultadas dessas obras foram (Rego 2008a, 2011d, 2012a, 2012c).

4 Edições consultadas dessas obras foram (Rego 2011b e 2011c).

5 O cangaço foi um tipo de banditismo existente no Nordeste brasileiro, principalmente na sub-região denominada Sertão. Os bandidos organizavam-se em bandos, sob a liderança de um chefe. É possível identificar os grupos de Cabeleira e de João Calangro como precursores do cangaço (Queiroz 1986). Mas foi da virada do XX em diante que o cangaço se consolidou. Foram líderes de maior notoriedade: Sinhô Pereira, Luiz Padre, Jesuíno Brilhante, Antônio Silvino, Lampião e Corisco. O tamanho do grupo variava. Silvino preferia grupo pequeno de uns seis homens. Lampião usualmente tinha em torno de cinquenta cangaceiros, podendo, em épocas de barulho chegar a duzentos. As vestimentas constituíam-se por roupas de couro, típicas dos vaqueiros da região, que necessitavam desse material para a proteção contra espinhos da vegetação xerófila predominante no clima semiárido da região. Mas, principalmente com Lampião, adornos de tecido e de metal foram incorporados aos chapéus e às roupas. Frederico Pernambucano de Mello (2012) pesquisou a interessantíssima estética do cangaço. Os bandidos e as forças policiais que os perseguiam andavam a pé pela caatinga, posto que animais de montaria não adentravam bem naquele tipo de vegetação. 
6 Outra representante dessa interpretação sobre o cangaço foi Maria Christina Russi da Matta Machado, com As táticas de guerra dos cangaceiros (1969). Para uma análise conjunta da obra, de seus processos constitutivos e de pesquisa e da própria biografia da autora, conferir Pericás (2019).

7 Hobsbawm (2015) revisaria em parte sua teoria com Bandidos, publicado em 1969.

8 O personagem Antônio Silvino, na ficção de Rego, corresponde ao cangaceiro homônimo de real existência.

9 O personagem coronel José Paulino, senhor do engenho Santa Rosa, que, no "Ciclo da cana-de-açúcar", representou na ficção o avô do romancista, também recebeu visitas amistosas do capitão em Menino de Engenho (Rego 2012b:40-41).

10 Lampião também possuía gado: “[...] a relação dos chefes bandoleiros com as elites locais era, em muitos casos, bastante estreita: tornavam-se aliados e amigos de muitos 'coronéis' do sertão. Por isso, o depoimento de Miguel Feitosa é ainda mais emblemático: 'Lampião dava a vida para estar entre 'coronéis'. Vivia de coronel em coronel. Não se deve estranhar, portanto, que o próprio Lampião fosse, ele próprio, criador de gado. De acordo com Rodrigues de Carvalho, em Sergipe, sua criação, na fazenda Canabrava, chegou a ter em torno de cem cabeças'" (Pericás 2010:36).

11 Pernambucano de Mello historiou a logística do cangaço que, por intermédio de coronéis poderosos, adquiria munição produzida a centenas de quilômetros. "Somente ligações de um tal porte com grandes proprietários rurais - a dupla citada [coronel Chico Porfírio e coronel Hercílio] encabeçava à época a lista dos maiores latifundiários do Estado [Sergipe] - comerciantes e industriais que dispunham de portos próprios no baixo São Francisco, através dos quais transacionavam diretamente com o parque fabril de São Paulo, podem explicar o mistério aparente de certas denúncias como a que fez o Correio de Aracaju, em sua edição de 25 de junho de 1937: Lampião estava utilizando nesse ano munição datada de 1932" (Pernambucano de Mello 2011:276).

12 Conta o historiador Frederico Pernambucano de Mello (2011:300-301) que Lampião, em meados da década de 30, sem o mesmo vigor físico de outrora, passava longas épocas de retirada em Sergipe. Roberto Lyra registrou: "A primeira pessoa com quem Lampeão se relacionou nas terras do novo Estado, que vinha desgraçar, foi o coronel Petronilho, no logarejo Varzea da Ema, rico fazendeiro da região. O coronel, dispensando-lhe, para logo, deliberada e ostensiva proteção [...] forneceu-lhe animaes e o mandou para a fazenda Gangorra, de sua propriedade, onde o bandido se deleitou por alguns mezes em tranquillidade doce, refazendo-se das ultimas tropelias em territorio pernambucano" (Lyra 1936:574).

13 "De um laço de vista geral, poder-se-ia fixar o cangaceirismo clânico ou agrário [conceito próximo a relação entre senhores e cabras ou jagunços] e o cangaceirismo político. Isto é, o decorrente de concentração dos núcleos de fazendas, com seus agregados, pequenos feudos que rivalizaram em lutas incruentas, nos tempos coloniais. E, já dentro da República, lutas por motivos políticos entre coronéis sertanejos 
dominando os municípios, influindo nas eleições, tendo as urnas como motivo central das competições. Bem sabemos que, no fundo, as molas são econômicas, e revertem nesse sentido. Nos últimos quartéis do século, o banditismo, que se desprendeu da propriedade rural, por cissiparidade, autonomizou-se em grupos volantes, agindo por conta própria; e aceitando empreitadas por vêzes políticas [...]" (Menezes 1970:23).

14 Parte da historiografia deste século colocou em xeque a teoria da cissiparidade. Frederico Pernambucano de Melo (2011:68-70) almejou negar a relação ao demonstrar que líderes famosos de bandos não haviam sido jagunços ou capangas anteriormente. Luiz Bernardo Pericás (2010:28-29) e Grunspan-Jasmin (2006:25), por outro lado, vinculam-se mais à tradição iniciada por Menezes.

15 Gustavo Barroso (1930:57) dá notícia histórica de exemplo bárbaro do cangaço vingança: "Não há muitos annos, na luta entre Carvalhos e Pereiras, no sertão pernambucano, um official de policia, partidario dos primeiros, surpreendeu na estrada de Belmonte o joven Sebastião Pereira, rapaz morigerado, e obrigou-o de carabinas e baionetas, a engolir três cigarrros accêsos. Antes, depredára fazendas e villas, e surrára outros Pereiras. Sebastião, para vingar-se da affronta, matou-o de tocaia e tornou-se um cangaceiro terrível".

16 Petrônio Domingues (2017) fez reconstrução histórica interessante sobre a perícia criminológica realizada em Manuel Luiz de Jesus, o conhecido Corisco Preto, do bando de Lampião.

17 Para verificar como se operacionalizou a incorporação de Lombroso por Nina Rodrigues, confira Luciano Góes (2016). Para análises sobre a Escola Positiva brasileira, ver Ricardo Sontag (2014) e Rebeca Fernandes Dias (2017).

18 "Para Euclydes o mestiço é um desequilibrado incuravel, pois não encontra therapeutica para o combater de tendencias antagonicas das raças repentinamente aproximadas, fundidas num organismo isolado. Por isso mesmo, quando, hybridamente, apresenta vigor mental repousa sobre uma moralidade rudimentar, em que se pressente o automatismo impulsivo das raças inferiores" (Lyra 1936:563). Confira o subcapítulo "Antropologia Criminal", em Schwarcz (2005), para interessantes fontes acerca da tese sobre a degeneração do mestiço.

19 “Numa entrevista ao diário A Tarde, de 23 de março de 1932, Ramos [...] dizia ao repórter, categoricamente: 'Nenhuma das clássicas anomalias lombrosianas - cabeça disforme, face prognata; malares salientes; sobrecenho carregado; olhar "duro" e mau; orelhas malformadas [foram encontradas]"" (Pericás 2010:128).

20 “E estamos na presença de Antônio Silvino, um velho que me desnorteia, afugenta a imagem que eu havia criado, tipo convencional, símbolo idiota, caboclo ou mulato que, medido por um dos médicos encarregados de provar que os infelizes são degenerados, servissem bem: testa diminuta, dentes acavalados. Cabelo pixaim, olhos parados e sem brilho, enfim um desses pobres-diabos que morrem no eito e não fazem grande falta, aguentam facão de soldado nas feiras das vilas e não se queixam. Enganei-me, estupidamente" (Ramos 2014:67). 


\section{Referências bibliográficas}

ALMEIDA, José Américo de. 2008. "Coiteiros". In:__ Novelas: Reflexões de uma Cabra, O Boqueirão, Coiteiros. 3. ed. João Pessoa: Fundação José Américo de Almeida.

ALMEIDA, José Maurício Gomes de. 1999. A Tradição Regionalista no Romance Brasileiro (1857-1945). Rio de Janeiro: Topbooks.

BARROSO, Gustavo. 1930. Almas de lama e de aço (Lampeão e outros cangaceiros). São Paulo: Melhoramentos de São Paulo.

BUENO, Luís. 2015. Uma história do Romance de $30.1^{\mathrm{a}}$ reimpr. São Paulo: Editora da Universidade de São Paulo/Campinas.

CÂNDIDO, Antônio. 1991. "Um romancista da decadência". In: Eduardo F. Coutinho \& Ângela Bezerra de Castro (orgs.), José Lins do Rego. João Pessoa: Edições Funesc. pp. 392-397.

CARVALHO, José Murilo. 1997. “Mandonismo, Coronelismo, Clientelismo. Uma discussão conceitual". Dados - Revista de Ciências Sociais, 40 (2) :229-250

CASTELlO, José Aderaldo. 1961. José Lins do Rêgo: Modernismo e Regionalismo. São Paulo: Edart.

CHANDLER, Billy Jaynes. 1981. Lampião, o rei dos cangaceiros. Rio de Janeiro: Paz e Terra.

COSTA PINTO, Luiz de Aguiar. 1949. Lutas de Familias no Brasil. São Paulo: Companhia Editora Nacional.

COUTINHO, Edilberto. 1980. O romance do Açúcar: José Lins do Rego - vida e obra. Rio de Janeiro: José Olympio.

CUNHA, Euclides da. 2014. Os sertões. Lisboa: Glaciar.

DIAS, Rebeca Fernandes. 2017. Criminologia no Brasil. Rio de Janeiro: Lumen Juris.
DIÉGUES JÚNIOR, Manuel. 1991. "O romance do cangaço". In: Eduardo F. Coutinho \& Ângela Bezerra de Castro (orgs.), José Lins do Rego. João Pessoa: Edições Funesc. pp. 456-459.

DOMINGUES, Petrônio. 2017. "O 'Corisco Preto': Cangaço, raça e banditismo no Nordeste brasileiro". Rev. hist., São Paulo, 176:1-39.

FACÓ, Ruy. 2009. Cangaceiros e Fanáticos: Gênese e Lutas. Rio de Janeiro: UERJ.

FARIAS, Sônia Lúcia Ramalho de. 2006. O Sertão de José Lins do Rego e Ariano Suassuna: Espaço Regional, Messianismo e Cangaço. Recife: Ed. Universitária da UFPE.

FREYRE, Gilberto. 1967. Nordeste: aspectos da influência da cana sôbre a vida e a paisagem do Nordeste do Brasil. 4. ed. Rio de Janeiro: José Olympio.

2003. Casa-grande \& Senzala: formação da família brasileira sob o regime da economia patriarcal. 48. ed. rev. São Paulo: Global.

GÓES, Luciano. 2016. A “tradução" de Lombroso na Obra de Nina Rodrigues - O racismo como base estruturante da Criminologia brasileira. Rio de Janeiro: Revan.

GRUNSPAN-JASMIN, Élise. 2006. Lampião, Senhor do Sertão. São Paulo: USP.

GUSMÃO, Clóvis de. 1991. '“A terra é quem manda em meus romances': reportagem". In: Eduardo F. Coutinho \& Ângela Bezerra de Castro (orgs.), José Lins do Rego. João Pessoa: Edições Funesc. pp. 52-56.

HOBSBAWM, Eric J. 1983. Rebeldes primitivos: Estudio sobre las formas arcaicas de los movimientos sociales en los siglos XIX y XX. Barcelona: Ariel. 
2015. Bandidos. 4. ed. São Paulo: Paz \& Terra.

HOLLANDA, Bernardo Borges Buarque de. 2012. ABC de José Lins do Rego. Rio de Janeiro: José Olympio.

IBGE. 2017. Pernambuco, São José do Belmonte, Histórico. Disponível em: https://cidades.ibge.gov.br/v4/brasil/ pe/sao-jose-do-belmonte/historico. Acesso em 15/03/2019.

LEAL, Victor Nunes. 1980. "O coronelismo e o coronelismo de cada um". Dados - Revista de Ciências Sociais, 23 (1):11-14.

. 2012. Coronelismo, enxada e voto: O município e o regime representativo no Brasil. 7. ed. São Paulo: Companhia das letras.

LOMBROSO, Cesare. 2010. O homem delinquente. $1^{\mathrm{a}}$ reimpr. São Paulo: Ícone.

LUKÁCS, Georg. 1965. "Narrar ou descrever". In: Ensaios sobre literatura. Rio de Janeiro: Civilização Brasileira. pp. 43-94.

LYRA, Roberto. 1936. "Direito Penal: parte geral". In: Roberto Lyra \& Nelson Hungria (orgs.), Compendio de Direito Penal. Vol. 1. Rio de Janeiro: Livraria Jacyntho. 4 vols.

1974. Direito Penal Científico (Criminologia). Rio de Janeiro: José Konfino.

MACHADO, Christina Matta. 1969. As táticas de guerra dos cangaceiros. Rio de Janeiro: Laemmert.

MAGALHÃES DRUMMOND, José de. 1944. Comentários ao código penal (Decreto lei n. 2.848, de 7 de dezembro de 1940). Vol. IX. Rio de Janeiro: Revista Forense.

MENEZES, Djacir. 1970. O Outro Nordeste: ensaio sôbre a evolução social e política da "civilização do couro" e suas implicações históricas e nos problemas gerais. 2. ed. refundida e aum. Rio de Janeiro: Artenova.
NINA RODRIGES, Raymundo. 1957. As raças humanas e a responsabilidade penal do Brasil. Salvador: Progresso. . 2010. Os Africanos no Brasil. Rio de Janeiro: Centro Edelstein de Pesquisas Sociais.

OLIVEIRA, Aglae Lima de. 1970. Lampião, Cangaço e Nordeste. Rio de Janeiro: O Cruzeiro.

PEREGRINO, Miriane da Costa. 2013. "Literatura de príncipe herdeiro" ou literatura engajada?: dilemas de José Lins do Rego. Dissertação de Mestrado, Universidade do Estado do Rio de Janeiro.

PERICÁS, Luiz Bernardo. 2010. Os cangaceiros: ensaio de interpretação histórica. São Paulo: Boitempo.

2019. "Uma intérprete do cangaço". Revista do Instituto de Estudos Brasileiros, 72:200-210.

PERNAMBUCANO DE MELLO, Frederico. 2011. Guerreiros do Sol: Violência e banditismo no Nordeste do Brasil. 5. ed. rev. e atualiz. São Paulo: A Girafa.

2012. Estrelas de couro: a estética do cangaço. 2. ed. São Paulo: Escrituras.

PERRUCI, Gadiel. 1978. A república das Usinas. Um estudo de história social e econômica do nordeste: 1889-1930. Rio de Janeiro: Paz e Terra.

QUEIROZ, Maria Isaura Pereira 1976. O mandonismo local na vida política brasileira e outros ensaios. São Paulo: Editora Alfa-omega.

. 1977. Os cangaceiros. São Paulo: Livraria Duas Cidades. . 1986. História do Cangaço. São Paulo: Global.

RAMOS, Graciliano. 2014. Cangaços. Organizado por Ieda Lebensztayn e Thiago Mia Salla. Rio de Janeiro: Record.

REGO, José Lins do. 1945. Poesia e Vida. Rio de Janeiro: Editora Universal. 
1957. A presença do nordeste na literatura. Rio de Janeiro: Ministério da Educação e Cultura.

1977. Doidinho: romance. 15. ed. Rio de Janeiro: José Olympio.

2004. O cravo de Mozart é eterno: crônicas e ensaios. Organizado por Lêdo Ivo. Rio de Janeiro: José Olympio.

. 2008a. Eurídice: romance. 10. ed. Rio de Janeiro: José Olympio.

. 2008b. Meus verdes anos: memórias. 8. ed. Rio de Janeiro: José Olympio.

. 2008c. Moleque Ricardo: romance. 27. ed. Rio de Janeiro: José Olympio.

2009. Fogo Morto: romance. 68.

ed. Rio de Janeiro: José Olympio. . 2011a. Banguê: romance. 23. ed.

Rio de Janeiro: José Olympio.

. 2011b. Cangaceiros: romance.

15. ed. Rio de Janeiro: José Olympio. . 2011c. Pedra Bonita: romance.

15. ed. Rio de Janeiro: José Olympio. 2011d. Riacho Doce: romance.

22. ed. Rio de Janeiro: José Olympio. 2012a. Água-mãe: romance. 13.

ed. Rio de Janeiro: José Olympio. . 2012b. Menino de Engenho: romance. 103. ed. Rio de Janeiro: José Olympio.

.2012c. Pureza: romance. 12. ed. Rio de Janeiro: José Olympio. . 2012d. Usina: romance. 7. ed. Rio de Janeiro: José Olympio.

SCHWARCZ, Lilia Moritz. 2005. O espetáculo das raças: cientistas, instituições e questão racial no Brasil - 1870 -1930. São Paulo: Companhia das Letras.

SHAKER, Arthur. 1979. Pelo Espaço do Cangaceiro, Jurubeba. São Paulo: Símbolo.

SONTAG, Ricardo. 2014. "Código criminológico"?: Ciência jurídica e codificação penal no Brasil (1888-1899). Rio de Janeiro: Revan.

TELAROLLI, Rodolpho. 1982. Eleições e Fraudes Eleitorais na República Velha. São Paulo: Brasiliense.

TRIGO, Luciano. 2002. Engenho e Memória: o nordeste do açúcar na ficção de José Lins do Rego. Rio de Janeiro: Topbooks. 
LITERATURA OU ANTROPOLOGIA CRIMINAL? O CANGAÇO EM

PEDRA BONITA E CANGACEIROS

\section{Resumo}

Este artigo investiga as interpretações sociocriminológicas de José Lins do Rego sobre o cangaço que lhe serviram de pano de fundo para desenvolver os romances Pedra Bonita e Cangaceiros. Mostrase como o romancista se posicionava perante duas teorias criminológicas que, em sua época, tentavam compreender o cangaço: a teoria do banditismo social e a antropologia criminal da Escola Positiva brasileira. Conclui-se que o caminho trilhado por Rego para explicar a gênese do cangaço passava por entendê-lo em função das disputas coronelistas.

Palavras-chave: Cangaço, José Lins do Rego, Coronelismo, Antropologia criminal, História do Direito.
¿LITERATURA O ANTROPOLOGÍA

CRIMINAL? EL “CANGAÇO” EN

PEDRA BONITA Y CANGACEIROS

\section{Resumen}

Este artículo investiga las interpretaciones sociales y criminológicas de José Lins do Rego sobre el "cangaço", que le sirvieron de fondo para desarrollar los romances Pedra Bonita y Cangaceiros. Se muestra cómo el novelista se posicionaba ante dos teorías criminológicas que, en su época, intentaban comprender el "cangaço": la teoría del bandidismo social y la antropología criminal de la Escuela Positiva brasileña. Se concluye que el camino trillado por Rego para explicar la génesis del "cangaço" pasaba por entenderlo en función de las disputas del "coronelismo".

Palabras clave: "Cangaço", José Lins do Rego, "Coronelismo", Antropología criminal, Historia del Derecho. 
LITERATURE OR ANTHROPOLOGICAL CRIMINOLOGY? THE "CANGAÇO” IN PEDRA BONITA AND

\section{CANGACEIROS}

\begin{abstract}
This article investigates José Lins do Rego's socio-criminological interpretations of the "cangaço", which provided him with a background against which he developed the novels Pedra Bonita and Cangaceiros. It shows how
\end{abstract}

the novelist positioned himself between two criminological theories that, at that time, tried to understand the "cangaço": the theory of social banditry and the criminal anthropology of the Brazilian Positive School. It concludes that the path taken by Rego to explain the genesis of the "cangaço" involved understanding it as a function of "colonelist" disputes. Keywords: "Cangaço", José Lins do Rego, "Colonelism", Anthropological criminology, History of Law. 